\title{
Cytotoxic and Regulatory T-Cell Molecule
}

National Cancer Institute

\section{Source}

National Cancer Institute. Cytotoxic and Regulatory T-Cell Molecule. NCI Thesaurus.

Code C104174.

Cytotoxic and regulatory T-cell molecule (393 aa, $47 \mathrm{kDa}$ ) is encoded by the human CRT AM gene. This protein is involved in promoting natural killer (NK) cell cytotoxicity and may promote interferon-gamma (IFN-gamma) secretion by CD8+ cells. 